to $38^{\circ}$ Fah. and the barometer went down as low as 88.900 , on the 29 th, or three days after the tempest. Between September the 27th and Norember 7 th, the barometer has raried between 28.900 and 30.045 inches; its average height being 29.500 . During the storm, 0.57 of an inch of rain fell.

On the 21st of October, the magnet, whose declination was $20^{\circ}$, retrograded $1^{\circ}$, and marked $19^{\circ}$, east of the mag netic meridian. But there was an aurora of a ruddy tint, about 10 P.M., that night. In the Registrar General's Returns for the week ending Saturday, October 20th, it is stated, page 348 :- "A fine aurora was seen at night (18th Oct.), with coloured streamers; the magnets were much disturbed." On that night, in this locality, the magnet was quiet. It will be noticed that the aurora preceded the hurricane of the 26th October; and the other phenomena were altogether remarkable, viz.: an eclipse of the moon, the disturbance of the magnet, the sudden rise and fall of the barometer, the extreme capriciousness of the electrometer, the height of the thermometer, the quantity of rain that fell, and the force of the wind, which is calculated at $4 \cdot 0$, by Mr. Lowe, of Highfield House Observatory.

The prevailing direction of the wind Sept. 27th to Oct. 26th was S.W.W., but afterwards it blew from N.W.N., occasionally going round to the S.W., with plenty of rain. The storm of the 26th Oct. changed the state of the atmosphere, and the autumn was completely established. Until then, the weather was still summerlike, and fires were scarcely wanted.

To say that cloudy weather is dark, is very indefinite. The Greenwich meteorologists call it "cold and dull", which is the popular expression; but it is not accurate nor precise. During the storm of the 26th, it was only twilight, while on the 4th of November, the sunshine was as bright as in June. I have contrived an instrument of a very simple kind, by means of which I think I can arrive at the amount of each day's light, proximately, at least. It consists of a box, 6 inches long by 4 inches broad and 3 inches deep, lined with lamp-black, and its floor furnished with a white dial divided into eight spaces; the light enters through a slit, 1 inch high and $\frac{1}{8}$ inch broad at one end, while an eyelet hole in the roof permits you to look in and see the number to which the direct ray reaches. The light should be received from a clear north aspect at noon. This little contrivance is open to all sorts of objections, and capable of every kind of improvement; but it is good enough as far as it goes. Thus, I find, that-

$$
\begin{aligned}
& \text { Nov. 3rd, marks only } 4 \text { a dull day. }
\end{aligned}
$$

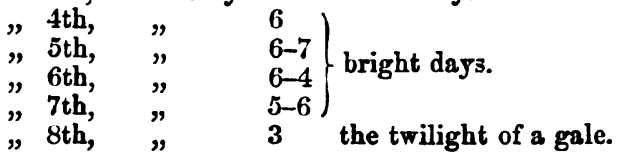

\section{CASE OF CHOREA.}

\section{By THOMAS BROWN, Esq., Manchester.}

Mrss E. L., a near neighbour, and a very interesting young lady, aged 17 years, belonging to the millinery business, came under my care on the 17th of March last for a very decided case of chorea. As is frequently usual in such cases, there was a perfect anæmic condition of the system, and distressing tedium vicæ. On giving my interesting patient my cane, the arm convulsively drew back; and on examining the tongue, it was tremulous; there was overy symptom of debility; and confinement in a garret at Southport, where there was very little ventilation, as well as long-continued application to needlework in the sitting posture, was sufficient causa proxima to account for every symptom. Without any delay a sudorific and aperient was administered; and so soon as the skin and bowels were corrected, a mixture of quinine and iron was prescribed. With this medicine, composed of citrate of iron and sulphate of quinine, and taken three times a-day, I gave-

B Pulv. rhei gr. Xv; ferri sesquichloridi $3 i$; ex theriacà.
A fow days only were requisite to give indication of a salutary change. The lips became ruddy, the tongue florid, the countenance happy; the power over the voluntary muscles well marked, and this delightful approximation to healthy action manifested by a full and complete grasp of the cane. From the 17th of April to the 14th of May the chalybeate and tonic mode of treatment was most admirably perserered in, and 2 complete recovery from a most repulaive malady the result.

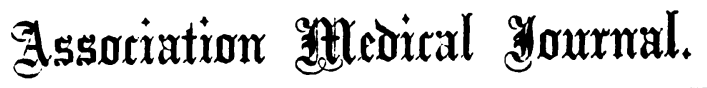

FRIDAY, NOVEMBER 23RD, 1855.

\section{THE SPECIAL MEETING AT BIRMINGHAM.}

The Birmingham Meeting of the 20th of November will ever be looked upon as a memorable one in the annals of our Association.

On that date an extraordinary convention, suddenly called together from all parts of the island, met in doubt, and perhaps distrust. Two sections of the Association, whose views had hitherto differed as to the best means of conducting the affairs of the Association, were to confront each other, either to heal or to destroy. The discord that for years had been slowly gaining strength was either to break out into uncontrollable disorder, or to be banished for ever from among us. Under such circumstances it was not to be wondered at that many anxious faces were seen at the commencement of the meeting, and many doubtful answers were given as to the manner in which its proceedings would terminate. In these doubts we must confess, however, we did not participate. We said last week that the real differences between the two sections were no longer worth contending for, and so it has proved. A few liberal and comprehensive resolutions on the part of the Executive Council, gracefully proposed by Sir Charles Hastings, and as gracefully accepted by Mr. Michael, Dr. Cowan, Mr. Ancell, and the other leaders of the late opposition, at once swept away every element of discord within the bosom of the Association, and in the bursts of cheering with which this happy accord was greeted, every member present folt that the Association was taking a new and lengthened lease of its existence. Meetings of this kind rarely presont any dramatic element, but on this occasion it was certainly apparent. Speakers that have hitherto honestly differed, by some harmonising influence were found honestly in agreement. Sir Charles Hastings, in the progressive race, touched the goal before Mr. Michael, only because he was the first to speak ; and Dr. Sibson, acting under the happy inspiration of the moment, was foremost to velcomo the amendments of the latter gentleman. Before half a dozen speeches had been made, the meeting breathed freely. Where was the opposition? Where the grating voice of dissent? Each speaker, as he got upon his legs, seemed to drop nothing but precious stones from his mouth, like the child in the fairy tale; and the scene, which some fancied would end in a miserable catastrophe, closed by the whole company taking hands before the footlights ere the curtain fell.

In speaking thus rejoicingly of the termination of Tuarday's meeting, wre are fully awrare of the grevity of the danger we have passed. It is nothing less than a revolu- 